Review

\title{
Market Demand and Production Capacity Expansion of Hydrogen Peroxide in Bangladesh
}

\author{
Mohammad Rafiqul Islam and Mohammad Khairul Islam Sarkar \\ Department of Environmental Science, Independent University, Bangladesh (IUB), Dhaka, Bangladesh
}

\author{
Article history \\ Received: 15-12-2016 \\ Revised: $28-12-2016$ \\ Accepted: 16-05-2017 \\ Corresponding Author: \\ Mohammad Rafiqul Islam \\ Department of Environmental \\ Science, Independent \\ University, Bangladesh (IUB), \\ Dhaka, Bangladesh \\ Email: sad.safwan@yahoo.com
}

\begin{abstract}
The work on production capacity expansion of hydrogen peroxide plants is part of an extensive research. In this research, the expansion of hydrogen peroxide plant, including the local current production and market demands of hydrogen peroxide has been highlighted. Hydrogen peroxide $\left(\mathrm{H}_{2} \mathrm{O}_{2}\right)$ is one of the basic chemicals. The market size of hydrogen peroxide in Bangladesh has been ever bigger than caustic soda. Textile, Dyeing, Medicine, Pharmaceuticals, Water Treatment, Soap, Pulp and Paper Industries are using hydrogen peroxide $\left(\mathrm{H}_{2} \mathrm{O}_{2}\right)$ as huge quantity. Recently new application is developed for hydrogen peroxide in the effluent treatment of various organic wastes of refineries and other chemical industries. In Bangladesh, there are only four plants which are producing various grades and qualities of hydrogen peroxide. Among these, three plants are producing the $50.00 \%(\mathrm{w} / \mathrm{w})$ and one plant is producing the $35.00 \%(\mathrm{w} / \mathrm{w})$ concentration of hydrogen peroxide. But locally, the consumption of $50.00 \%(\mathrm{w} / \mathrm{w})$ is higher than $35.00 \%(\mathrm{w} / \mathrm{w})$ concentration of hydrogen peroxide. The current production capacity of hydrogen peroxide in Bangladesh is not adequate to meet the country's requirement. In Bangladesh, production of hydrogen peroxide is about 190 Ton Per Day (TPD) but demand is 350 Ton per Day (TPD) which is higher than the local production. In that case, some quantity of $50.00 \%(\mathrm{w} / \mathrm{w})$ concentrates of hydrogen peroxide is being imported from foreign countries like as India, China, Korea and Thailand. To avoid imports the hydrogen peroxide and to meet the requirement of local consumers, either needs to install a new production plant or increase the capacity of the existing plant. Chemical Engineers recommend that the expansion of local plants is better than newly installed the plant and it will more competence. The main purpose of the study to introduce the answer regarding the basic question, "how will we expand the capacity of an existing $\mathrm{H}_{2} \mathrm{O}_{2}$ plant?" In this study, a complete expansion and operation data of the $\mathrm{H}_{2} \mathrm{O}_{2}$ manufacturing plant have been shown so that the plant can be run efficiently. Beside this, the properties, manufacturing procedures, applications and local demanding of hydrogen peroxide are briefly discussed in this study. Finally, this invention will be helpful for the engineering team, operation team and marketing team so that they can implement their own jobs in the expansion project.
\end{abstract}

Keywords: Hydrogen Peroxide, $\left(\mathrm{H}_{2} \mathrm{O}_{2}\right)$, Manufacture, Plant Profile, Local Demand, Beaching, Expansion, Existing, Capacity

\section{Introduction}

A chemical plant is an industrial process plant. The general objective of the chemical plant is to create new materials via the chemical transformation or separation. The chemical plant uses specialized raw materials, equipments, unites and technologies in the manufacturing process. Generally, the products of the chemical industry 
can divide into three categories: Basic chemicals, specialty chemicals and consumer chemicals. Hydrogen peroxide is a basic chemical which is being produced by the hydrogenation, oxidization, extraction and purification system in the manufacturing process (http://nzic.org.nz/ChemProcesses/production/1E.pdf). Firstly, the concentration of hydrogen peroxide makes $35.00 \%$ and concentrated it to $50.00 \%$ by a concentrated section. The $\mathrm{H}_{2} \mathrm{O}_{2}$ manufacturing plant runs through the continuous system and supplies the product through the batch process.

There are only four hydrogen peroxide industries in Bangladesh namely, HP Chemicals Industries Ltd, ASM Chemical Industries Ltd, TK Group Industries Ltd. (Samuda) and Tasnim Chemical Industries Ltd. Among them, 35.00\% (w/v) concentrate of hydrogen peroxide is being produced by only HP Chemicals Industries Ltd. and 50.00\% (w/w) concentrate of hydrogen peroxide is being produced by the remaining industries (Salahuddin, 2011). The design of a factory is made by a team including chemists, plant designers and chemical engineers for suitable construction. Just like the above sentences, need to make a team where will include engineers, chemists and operators for the expanding of existing production capacity. During the designing and planning of the expanding plant, they will study on a few factors such as technology, solution process, costing and typically as an initial screening to eliminate unprofitable designs. If the process appears profitable, then other factors will be considered, such as safety, environmental constraints, controllability etc. Suppose, if we want to increase the production capacity from 35 to 60 TPD as $50.00 \%$ concentrate. $\mathrm{H}_{2} \mathrm{O}_{2}$ at an investment of limited cost, we will think about the changing utilities, the designed parameters, calculating the consumption of raw materials, quality of raw materials and finished product etc. We investigated and visited the ASM Chemical Industries Ltd. A few months ago, they expanded their existing production capacity from 35 TPD to 60 TPD that means, it expanded from existing capacity 35 Ton day ${ }^{-1}\left(50.00 \%\right.$ conc. of $\left.\mathrm{H}_{2} \mathrm{O}_{2}\right)=57.7$ Ton day ${ }^{-1}\left(35.00 \%\right.$ conce. of $\left.\mathrm{H}_{2} \mathrm{O}_{2}\right)$ to $60 \mathrm{Ton}^{-1}$ $\left(50.00 \%\right.$ conce. of $\left.\mathrm{H}_{2} \mathrm{O}_{2}\right)=88.5$ Ton day ${ }^{-1}(50.00 \%$ conce. of $\mathrm{H}_{2} \mathrm{O}_{2}$ ) (https://asmchemical.com).

\section{Current Demand and Consumption}

Presently the apparent consumption data of Hydrogen Peroxide production and market demand in Bangladesh are shown in Table 1 and 2 (Salahuddin, 2011).

It was shown in (Fig. 1), the local demand of hydrogen peroxide had been doubled in the last twenty years, which was a matter of surprising.

Table 1. Production capacity of different industries in Bangladesh

\begin{tabular}{lllllll}
\hline Product name & $\begin{array}{l}\text { ASM chemicals } \\
\text { (capacity) }\end{array}$ & $\begin{array}{l}\text { Samuda chemicals } \\
\text { (capacity) }\end{array}$ & $\begin{array}{l}\mathrm{HP} \text { chemicals } \\
\text { (capacity) }\end{array}$ & $\begin{array}{l}\text { Tasnim chemical } \\
\text { (capacity) }\end{array}$ & $\begin{array}{l}\text { Total production } \\
\text { (capacity) }\end{array}$ & $\begin{array}{l}\text { Current } \\
\text { demand }\end{array}$ \\
\hline $\mathrm{H}_{2} \mathrm{O}_{2}(50.00 \%)$ & $60 \mathrm{MT}$ & $70 \mathrm{MT}$ & - & $60 \mathrm{MT}$ & $190 \mathrm{MT}$ & $350 \mathrm{MT}$ \\
$\mathrm{H}_{2} \mathrm{O}_{2}(35.00 \%)$ & - & - & $28 \mathrm{MT}$ & - & $28 \mathrm{MT}$ & $100 \mathrm{MT}$ \\
\hline
\end{tabular}

Table 2. Consumption of hydrogen peroxide in Bangladesh

\begin{tabular}{|c|c|}
\hline Year quantity & Demand of $\mathrm{H}_{2} \mathrm{O}_{2}$ Metric Ton (MT) \\
\hline Year of 96-97 & 76,551 \\
\hline Year of $97-98$ & 79,613 \\
\hline Year of $98-99$ & 82,798 \\
\hline Year of 99-00 & 86,109 \\
\hline Year of $00-01$ & 89,554 \\
\hline Year of 01-02 & 93,136 \\
\hline Year of $02-03$ & 96,861 \\
\hline Year of 03-04 & 100,736 \\
\hline Year of 04-05 & 104,765 \\
\hline Year of $05-06$ & 108,956 \\
\hline Year of $06-07$ & 113,314 \\
\hline Year of 07-08 & 117,847 \\
\hline Year of 08-09 & 122,561 \\
\hline Year of $09-10$ & 127,463 \\
\hline Year of $10-11$ & 132,560 \\
\hline Year of 11-12 & 135,890 \\
\hline Year of $12-13$ & 141,930 \\
\hline Year of $13-14$ & 145,327 \\
\hline Year of $14-15$ & 148,723 \\
\hline
\end{tabular}




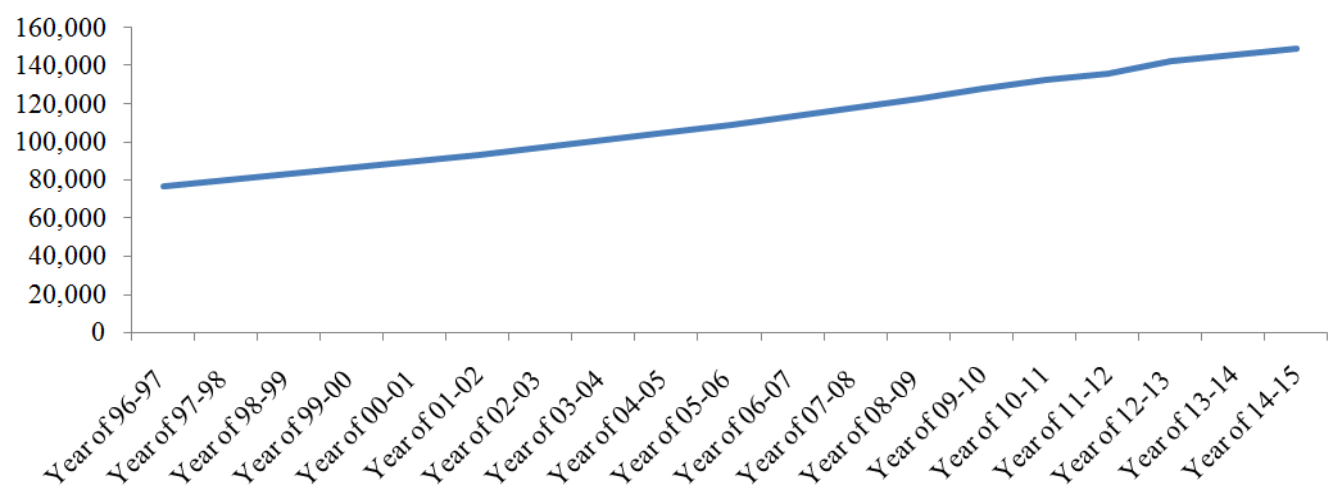

Fig. 1. Increasing the consumption rate of hydrogen peroxide

\section{Characteristics of Hydrogen Peroxide}

Hydrogen Peroxide is a chemical substance with the formula $\mathrm{H}_{2} \mathrm{O}_{2}$. In its pure form, it is a colorless liquid slightly more viscous than water. However, for safety reasons it is normally used as an aqua solution. Hydrogen peroxide is the simplest peroxide (a compound with an oxygen-oxygen single-bond) and finds use as a strong oxidizer, bleaching agent and disinfection. The concentrated hydrogen peroxide, or "high test peroxide", is a reactive oxygen species and has been used as a propellant in rocketry. Hydrogen peroxide is often described as being "water" but with one more oxygen atom", a description that can give the incorrect impression of significant chemical similarity between the two compounds. While they have a similar melting point and appearance, pure hydrogen peroxide will explode if heated to boiling, will cause serious contact burns to the skin and can set materials alight on contact. For these reasons it is usually handled as a dilute solution (household grades are typically $3-6 \%$ in the U.S. and somewhat higher in Europe) (https://en.wikipedia.org/wiki/). Its chemistry is dominated by the nature of its most unstable peroxide bond.

\section{Properties}

Hydrogen peroxide $\left(\mathrm{H}_{2} \mathrm{O}_{2}\right)$ is a weak acidic, colorless liquid, miscible with water in all proportions, was discovered by Thenard in 1818 and has been used industrially since the mid-19th century (https://www.diyspaceexploration.com/preparingmanufacture-hydrogen-peroxide). It is the simplest peroxide (molecules containing two oxygen atoms covalently bonded to one another) and is commercially available in aqueous solution over a wide concentration range. The main uses of hydrogen peroxide are in the preparation of other peroxides and as an oxidizing agent. The boiling point of $\mathrm{H}_{2} \mathrm{O}_{2}$ has been extrapolated as being $150.2^{\circ} \mathrm{C}$, approximately $50^{\circ} \mathrm{C}$ higher than water (http://nzic.org.nz/ChemProcesses/production/1E.pdf). Practically, hydrogen peroxide will undergo potentially explosive thermal decomposition if heated to this temperature. It may be safely distilled at lower temperatures under reduced pressure. In aqueous solutions hydrogen peroxide differs from the pure material due to the effects of hydrogen bonding between water and hydrogen peroxide molecules. Hydrogen peroxide and water form a eutectic mixture, exhibiting freezing-point depression; pure water has a melting point of $0^{\circ} \mathrm{C}$ and pure hydrogen peroxide of $-0.43^{\circ} \mathrm{C}$, but a $50 \%$ (by volume) solution of the two freezes at $-51^{\circ} \mathrm{C}$. The boiling point of the same mixtures is also depressed in relation with the mean of both boiling points $\left(125.1^{\circ} \mathrm{C}\right)$. It occurred at $114^{\circ} \mathrm{C}$. This boiling point is $14^{\circ} \mathrm{C}$ greater than that of pure water and $36.2^{\circ} \mathrm{C}$ less than that of pure hydrogen peroxide (https://en.wikipedia.org/wiki/). Density of an aqua solution of hydrogen peroxide is different as per the concentration of hydrogen peroxide which was given in the Table 3 (http://www.h2o2.com/technicallibrary/physical-chemical-properties). It is noted that the density of hydrogen peroxide increased with the temperature increasing which was shown in Fig. 2

\section{Specification of Hydrogen Peroxide}

Different grades of hydrogen peroxide produced different functions and different usage such as food grade, drug grade, industrial grade (technical and chemical grade). Basically, maximum hydrogen peroxide produced for industrial usages in Bangladesh. The specification of industrial grade hydrogen peroxide was shown in Table 4. Typically; these grades also contain proprietary formula stabilizers which were designed to address specific needs of industry. Food Grade" means that it was approved by the United States Department of Agriculture for use in food processing. 


\section{Density of $\mathrm{H2O2}$}

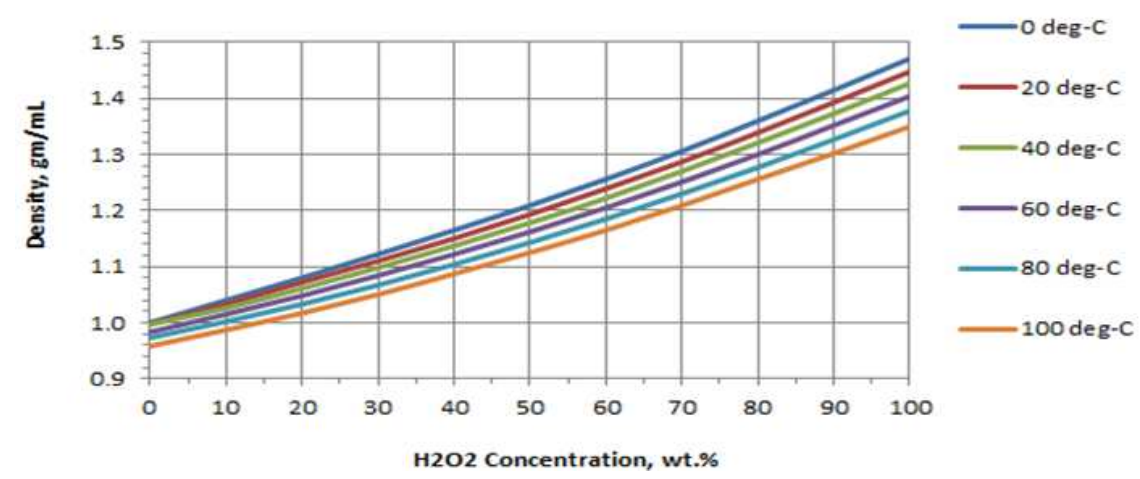

Fig. 2. Density or Specific Gravity of Hydrogen Peroxide; Ref: M.F. Easton, A.G. Mitchell, W.F.K. Wynne-Jones. Trans. Faraday Soc. 48:796 (1952)

Table 3. Density of $\mathrm{H}_{2} \mathrm{O}_{2}$ with temperatures

\begin{tabular}{lll}
\hline $\mathrm{H}_{2} \mathrm{O}_{2}(\mathrm{w} / \mathrm{w})$ & Density $\left(\mathrm{g} / \mathrm{cm}^{3}\right)$ & Temp $\left({ }^{\circ} \mathrm{C}\right)$ \\
\hline $3.0 \%$ & 1.0095 & 15 \\
$27 \%$ & 1.1000 & 20 \\
$35 \%$ & 1.1300 & 20 \\
$50 \%$ & 1.2000 & 20 \\
$70 \%$ & 1.2900 & 20 \\
$75 \%$ & 1.3300 & 20 \\
$96 \%$ & 1.4200 & 20 \\
$98 \%$ & 1.4300 & 20 \\
$100 \%$ & 1.4500 & 20 \\
\hline
\end{tabular}

Table 4. Specification of Hydrogen Peroxide, Industrial grade (http://www.cncec.com.cn; http://pureh2o2for health.com/whatish2o2.htm)

\begin{tabular}{lll}
\hline Parameters & $\mathrm{H}_{2} \mathrm{O}_{2}($ Conc.35.00\%) & $\mathrm{H}_{2} \mathrm{O}_{2}(\mathrm{Conc} .50 .00 \%)$ \\
\hline $\mathrm{HSCN}$ & 28470000 & 28111100 \\
$\mathrm{CAS}$ & $7722-84-1$ & $7664-39-3$ \\
Characteristics & Excellent grade (industrial) & Excellent grade (Industrial) \\
Appearance & Clear, colorless, transferring & Clear, colorless, transferring \\
$\mathrm{H}_{2} \mathrm{O}_{2} \%$ & 35.00 & 50.00 \\
Free acid content as $\mathrm{H}_{2} \mathrm{SO}_{4} \%$ & $0.04 \%$ & 0.04 \\
Stability \% & $>97.00$ & $>97.00$ \\
Non-Volatile Matters \% & $<0.08$ & $<0.08$ \\
TOC (PPM) & $<150.00$ & $<150.00$ \\
Specific gravity $@ 20^{\circ} \mathrm{C}$ & 1.13 & 1.19 \\
\hline
\end{tabular}

Specifically, it means that the United States Department of Agriculture has tested samples of a production run to certify that it is not contaminated, that its concentration level is the level stated and that it does not contain harmful stabilizers. Industrial grade of hydrogen peroxide is also manufactured in concentrations ranging from 20 to $70 \%$ for use in industrial, chemical and manufacturing applications which are not fit for use in food preparation or for agricultural or domestic home uses (http://www.h2o2.com/technicallibrary/physical-chemical-properties).

Drug store/grocery store grade hydrogen peroxide, available in a $3.00 \%$ solution is always stabilized to increase the shelf life of the product. Total fifteen grades of hydrogen peroxide are found in the world based on their applications (https://en.wikipedia.org/wiki/; http://h2o2uses.com/hydrogen-peroxide-grades-andstabilizers).

Product grade(s):

- $\quad$ PFP 35\% Hydrogen Peroxide

- AG Bath 35\% Hydrogen Peroxide

- AG Dual 35\% Hydrogen Peroxide

- HP Food 35\% Hydrogen Peroxide

- Chemical Grade 35\%

- Cosmetic Grade 35\%

- Food Grade 35\% Hydrogen Peroxide

- Universal Food Grade 35\% Hydrogen Peroxide

- Standard 35\% Hydrogen Peroxide

- $\quad$ Storage Grade 35\% Hydrogen Peroxide

- Technical Grade 35\% Hydrogen Peroxide 
- $\quad$ 12.Technical Grade 35/D Hydrogen Peroxide

- Technical Grade 40\% Hydrogen Peroxide

- $\quad$ Crude Grade $40 \%$ Hydrogen Peroxide

- AG Spray 35-S Grade Hydrogen Peroxide

\section{Methodology}

The first record of commercial production of hydrogen peroxide appeared in the 1865 to 1875 period. The first commercial production in the United States was by the Oakland Chemical Company, Brooklyn, New York, in 1881. Laporte Chemicals Ltd. established a factory in Yorkshire, England in 1888 (https://www.diyspaceexploration.com/preparingmanufacture-hydrogen-peroxide). With the exception of the substitution of Fluoro-silicic acid in the hydrochloric acid, Thenard's process was used essentially unchanged for the manufacture of hydrogen peroxide until nearly 1900. The formation of hydrogen peroxide in the electrolysis of sulfuric acid was first reported in 1853; later developments made the manufacture of hydrogen peroxide by an electrolytic process possible in 1908 . By 1939 , only $10 \%$ of the world's production was by the barium peroxide process (http://www.idconline.com/technical_references/pdfs/ch emical_engineering/Preparing_to_Manufacture_Hydroge n_Peroxide.pdf). Currently, hydrogen peroxide is commercially manufactured either by an electrolytic (inorganic) method or one of two organic processes. The electrolytic process involves the electrochemical formation of peroxydisulfuric acid or peroxydisulfate (from an ammonium bisulfate solution), their subsequent hydrolysis and separation hydrogen peroxide (https://www.diyspaceexploration.com/preparingmanufacture-hydrogen-peroxide;

http://www.idconline.com/technical_references/pdfs/che mical_engineering/Preparing_to_Manufacture_Hydroge n_Peroxide.pdf).

One of the organic processes used commercially for the manufacture of hydrogen peroxide involves the catalytic reduction of a substituted anthraquinone and subsequent oxidation back to the quinone structure with the production of $\mathrm{H}_{2} \mathrm{O}_{2}$. Detail explanation of anthraquinone method which dissolves in an appropriate organic solvent, are used as reaction media. The organic solvent is usually a mixture of several organic solvents. The solution obtained by dissolving the anthraquinone in the organic solvent is called "Working Solution" The anthraquinone in the working solution are subjected to reduction with hydrogen in presences of a Paladium(Pd) catalyst to produce anthrahydroquinones (http://www.cncec.com.cn; Kato et al., (n.d.)). In Bangladesh, hydrogen is generally obtained from natural gas.

The anthrahydroquinones are oxidized with air. In this step one mole of hydrogen peroxide is formed per one mole of oxidized anthrahydroquinone. Hydrogen peroxide produced in working solution after the above mentioned steps. It is separated from the working solution by extraction with water. The working solution from which hydrogen peroxide has been separated is returned to the reduction step again, thereby forming a cyclic process (http://www.cncec.com.cn). Produced hydrogen peroxide is concentrated in another concentration unite by distillation, condensation and vacuum system. The section includes the principles of different segments of the manufacturing process which include working solution preparation, hydrogenation, oxidation, extraction and purifications

\section{Working Solution Preparation}

2-Ethyle Anthra Quinone (2-EAQ) is dissolved in two solvents. One is non polar and another is polar (http://www.cncec.com.cn; Kosydar et al., 2010). Collectively the anthraquinone and solvents are called the working solution. Large amount of Heavy Aromatics (AH) and Tri Octyle Phosphate (TOP) needs to prepare working solution. Both solvents require distilling for removing the colloidal matter, impurities etc.

Chemical reactions are given as follow (Fig. 3).

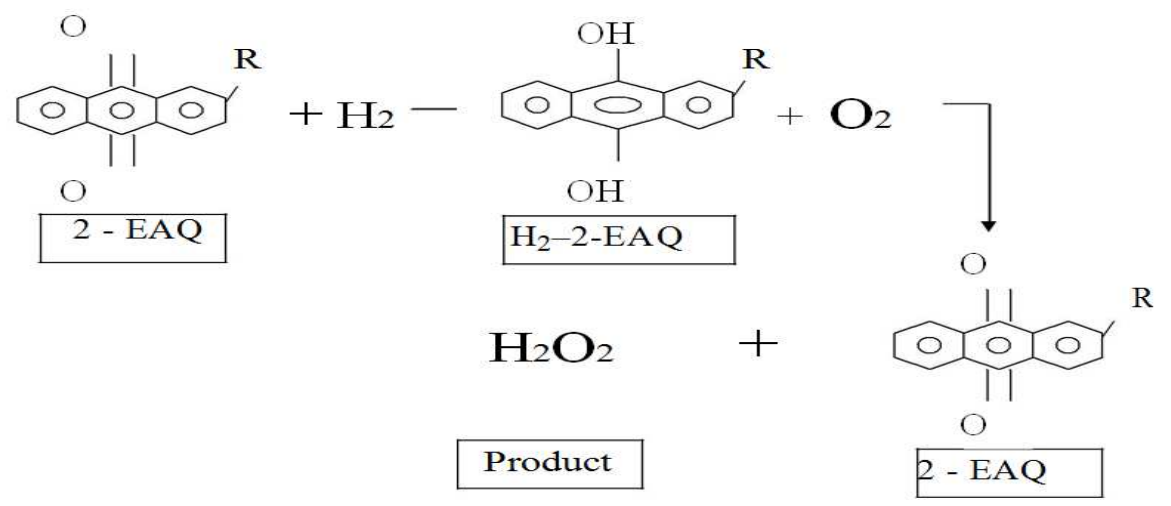

Fig. 3. Chemical reaction for producing hydrogen peroxide 
Preparation of one cubic meter of working solution needs $136 \mathrm{~kg}$ of 2-EAQ with the ratio of Heavy Aromatics to Tri Octyle Phosphate:: 75:25 (http://www.cncec.com.cn). This working solution is recycled.

\section{Hydrogenation}

During production, working solution with heated hydrogen combined sent to the hydrogenation tower and (Raw heated hydrogen comes to the hydrogenation tower from the hydrogen generation plant). Hydrogenation system is three sections series and operation individually at the same time; each section is filled with 4.0 Ton palladium catalyst. After reaction in each section, working will go tom the separator where separate the hydrogen tail gas and hydrogenated working solution (http://www.cncec.com.cn):

- $\mathrm{H}_{2} \mathrm{O}_{2}$ Production = Hydrogenated Efficiency $\mathrm{X}$ Working solution flow $=7.8 \mathrm{~g} \mathrm{~L}^{-1} \times 165.38 \mathrm{~m}^{3} / \mathrm{hr}=$ $1290 \mathrm{~kg} / \mathrm{hr}=1.290 \mathrm{Ton} / \mathrm{hr}(100 \%$ basis $)=88.5 \mathrm{TPD}$ (35\%Conc. basis)

- $\quad$ Equally, $7.8 \mathrm{~g} \mathrm{~L}^{-1} \times 165.38 \mathrm{~m}^{3} / \mathrm{hr}=1290 \mathrm{~kg} / \mathrm{hr}=$ $1.290 \mathrm{Ton} / \mathrm{hr}(100 \%$ basis $)=88.5 \mathrm{TPD}(35 \%$ Conc. basis). If $136 \mathrm{gm} \mathrm{L}^{-1}$ of EAQ is contained in one liter of working solution and hydrogenation degree is $40.00 \%$, then Hydrogen Efficiency will be $=$ $136.45 \times 40.0 \times 34.01 / 238 \times 100=7.8 \mathrm{~g} \mathrm{~L}^{-1}$ (Min.)

- Note that, to reduce the quantity of hydrogen efficiency, working solution flow will be increased

- From above calculation, we can be operated the plant following conditions

- Conditions of Hydrogenation operation are as follows (http://www.cncec.com.cn)

- Pressure: More favorable the hydrogenation reaction in high pressure, but excess pressure can be pay off the decrease of Pd catalyst activity. Normally pressure of hydrogenation shall be $0.3 \sim 0.4 \mathrm{Mpa}$ in upper bed and lower bed pressure shall be about $0.25 \sim 0.3 \mathrm{Mpa}$. Both working solution and $\mathrm{H}_{2}$ gas shall be heated to $40^{\circ} \mathrm{C}$ :

- Temperature :45-55 degree Celsius

- Flow: Working solution flow in fixed bed is 165.37 $\mathrm{m}^{3} / \mathrm{hr}$

- Hydrogen Efficiency: 7.60 8.00 $\mathrm{g} \mathrm{L}^{-1}$, Formula: Maq/MAQ X $40.0 \% \mathrm{X} \mathrm{M} \mathrm{H}_{2} \mathrm{O}_{2}$ )

- Here, $\mathrm{mAQ}=$ Amount of EAQ $\mathrm{g} \mathrm{L}^{-1}$, MAQ = Molecular weight of EAQ, $\mathrm{M} \mathrm{H}_{2} \mathrm{O}_{2}=$ Molecular weight of $\mathrm{H}_{2} \mathrm{O}_{2}$

- Hydrogen flow: 950-1000 Nm³ $/ \mathrm{hr}$

\section{Oxidation}

Hydrogenation working solution cool to $45^{\circ} \mathrm{C}$ temperatures and enter into the bottom of the upper section of the oxidation tower. The oxidation tower is consisting of two sections, with each section connected to the fresh air. Then the reacted solution goes to separator for separate the tail gas and oxidation solution.

Conditions of oxidation operation are given below (http://www.cncec.com.cn):

- $\quad$ As oxidizing Yield: $90 \%$ (Min)

- Oxygenated Temperature: $50-55^{\circ} \mathrm{C}$

- Oxygenated solution Flow: $165.37 \mathrm{~m}^{3} / \mathrm{hr}$

- Air Flow: $5492.32 \mathrm{Nm}^{3} / \mathrm{hr}$

- Oxygenated Efficiency: $7.02 \mathrm{~g} \mathrm{~L}^{-1}$ (Min.)

- Efficiency Ratio: 90.0\% (Min.)

- Oxygenated solution Acidity: 0.002-0.0060 g L

\section{Extraction and Purification}

Leaving the oxidation tower, oxidizing solution is delivered into the extraction tower from the bottom beside this, pure water sent to the same tower from upper where they undergo a counter current contact. In there, the original working solution and produced hydrogen peroxide ( $35.00 \%$ conc.) are separated and produced $\mathrm{H}_{2} \mathrm{O}_{2}$ sent to the purification tower. After purification, $35.00 \%$ hydrogen peroxide sent to concentration unit to $50.00 \%$ concentrated of $\mathrm{H}_{2} \mathrm{O}_{2}$.

Conditions of extraction tower operation (http://www.cncec.com.cn):

- Oxygenated solution flow: $165.37 \mathrm{~m}^{3} / \mathrm{hr}$ Extraction Column Temperature: $45-50^{\circ} \mathrm{C}$

- Pure water flow: $2.5-3.0 \mathrm{~m}^{3} / \mathrm{hr} \mathrm{H}_{2} \mathrm{O}_{2}$ Content in extract solution: $396-410 \mathrm{~g} \mathrm{~L}^{-1}$

- Flow rate of Working Solution: $165.37 \mathrm{~m}^{3} / \mathrm{hr}$, Alkalinity of working solution; $0.00 \sim 0.0050 \mathrm{~g} \mathrm{~L}^{-1}$

\section{Working Solution Regeneration}

Hydrogenation generates not only peroxideproducing anthrahydroquinones but also some byproducts. These by-products include anthraquinone species that can be converted back to useful quinones by regeneration. During the regeneration process, a sidestream of working solution is fed through a bed of dehydrogenation catalyst. The regeneration converts deoxidized anthraquinones and tetrahydroanthraquinones to their corresponding anthraquinones. Specific gravity of $\mathrm{K}_{2} \mathrm{CO}_{3}: 1.4$ at $25^{\circ} \mathrm{C}$. Block flow diagram of $\mathrm{H}_{2} \mathrm{O}_{2}$ producing plant is shown in Fig. 4.

\section{Requirement Utilities and Raw Materials}

This plant processes natural gas through a steam reforming stage and subsequent high temperature shift catalytic stage to produce high purity hydrogen gas. The gas is finally purified in a pressure swing absorber 
before being used by the hydrogenation. Beside this, High purity water is used to feed the extractor, concentrator as well as the package boiler. Conventional degassing followed by cation and anion exchange beds is used to purify town water for use in the peroxide production (https://asmchemical.com; http://www.cncec.com.cn):

- $\quad$ Required $\mathrm{H}_{2}$ gas (Purity 99.0\%) for 57.7 TPD (35.00\% conc. $\mathrm{H}_{2} \mathrm{O}_{2}$ ):

$=22.4 \times 2.018 \times 57.7 \times 1000 \times 1000 / 97.17 \times 2.016 \times 1000$

$=13314.42 \mathrm{Nm}^{3} /$ day

$=554.76 \mathrm{Nm}^{3} / \mathrm{hr}\left(100 \%\right.$ basis $\left.\mathrm{H}_{2}\right)=560.36 \mathrm{Nm}^{3} / \mathrm{hr}$ (99.00\% basis $\mathrm{H}_{2}$ )

$=616.36 \mathrm{Nm}^{3} / \mathrm{hr}$ (include $10 \%$ extra basis)

Or, $256.37 \mathrm{Nm}^{3} /$ Ton $\left(35.00 \% \mathrm{H}_{2} \mathrm{O}_{2}\right.$ basis $)$

Required $\mathrm{H}_{2}$ gas (purity 99.0\%) for proposed 88.5 TPD $\left(35.00 \%\right.$ conc. $\left.\mathrm{H}_{2} \mathrm{O}_{2}\right)$ :

$=22.4 \times 2.018 \times 88.8 \times 1000 \times 1000 / 97.17 \times 2.016 \times 1000$

$=20490.82 \mathrm{Nm}^{3} /$ day

$=853.78 \mathrm{Nm}^{3} / \mathrm{hr}\left(100 \%\right.$ basis $\left.\mathrm{H}_{2}\right)=854.63 .36$

$\mathrm{Nm}^{3} / \mathrm{hr}\left(99.00 \%\right.$ basis $\left.\mathrm{H}_{2}\right)$

$=945.37 \mathrm{Nm}^{3} / \mathrm{hr}$. (including 10\% extra)

Or, $256.37 \mathrm{Nm}^{3} /$ Ton $\left(35.00 \% \mathrm{H}_{2} \mathrm{O}_{2}\right.$ basis $)$

- $\quad$ Required Air for 57.7 TPD (35.00\%Conc $\mathrm{H}_{2} \mathrm{O}_{2}$ basis)

$=22.4 \times 19.00 \times 57.7 \times 1000 \times 1000 / 97.17 \times 15.999 \times 1000$

$=15796.19 \mathrm{Nm}^{3} /$ day
$=658.17 \mathrm{Nm}^{3} / \mathrm{hr}\left(20 \% \mathrm{O}_{2}\right.$ basis $) \sim 3290.87 \mathrm{Nm}^{3} / \mathrm{hr}$ (Air basis)

$=3580.87 \mathrm{Nm}^{3} / \mathrm{hr}$ Air (include $10 \%$ extra basis)

Or $1489.44 \mathrm{Nm}^{3} /$ Ton (35.00\% Conc. $\mathrm{H}_{2} \mathrm{O}_{2}$ basis)

Similarly,

Required Air for proposed 88.5 TPD (35.00\% conc. $\mathrm{H}_{2} \mathrm{O}_{2}$ basis $)=5492.32 \mathrm{Nm}^{3} / \mathrm{hr}$

- Required Working Solution for 57.7 TPD: $250 \mathrm{~m}^{3}$ Approx. (Tank volume $50.00 \%$ conc. basis)

(Here, required working solution for proposed 88.5 TPD: $450 \mathrm{~m}^{3}$ Approx. (Tank volume 50.00\% conc. basis)

Similarly, Required 2- EAQ for proposed 88.5 TPD: $136 \mathrm{~g} \mathrm{~L}^{-1}$

Here:

- Molecular Weight of 2-EAQ = 236.00 (http://chemcollective.org/activities/tutorials/stoich/ calculating_molecular_weight)

- Molecular Weight of $\overline{\mathrm{H}}_{2}-\mathrm{EAQ}=238.016$

- Molecular Weight of $\mathrm{H}_{2} \mathrm{O}_{2}=34.01$

- Molecular Weight of $\mathrm{H}_{2}=2.016$

- Molecular Weight of $\mathrm{O}_{2}=15.99$

- $\quad$ Purity of $\mathrm{H}_{2}$ gas $=99.00 \%$

- $\quad 34.01$ Ton (based on $100 \%$ conc. $\mathrm{H}_{2} \mathrm{O}_{2}$ ) $=97.17$ Ton (based on $35.00 \%$ conc. $\mathrm{H}_{2} \mathrm{O}_{2}$ )

- At NTP- Volume of one molar gas $=22.4$ Liter

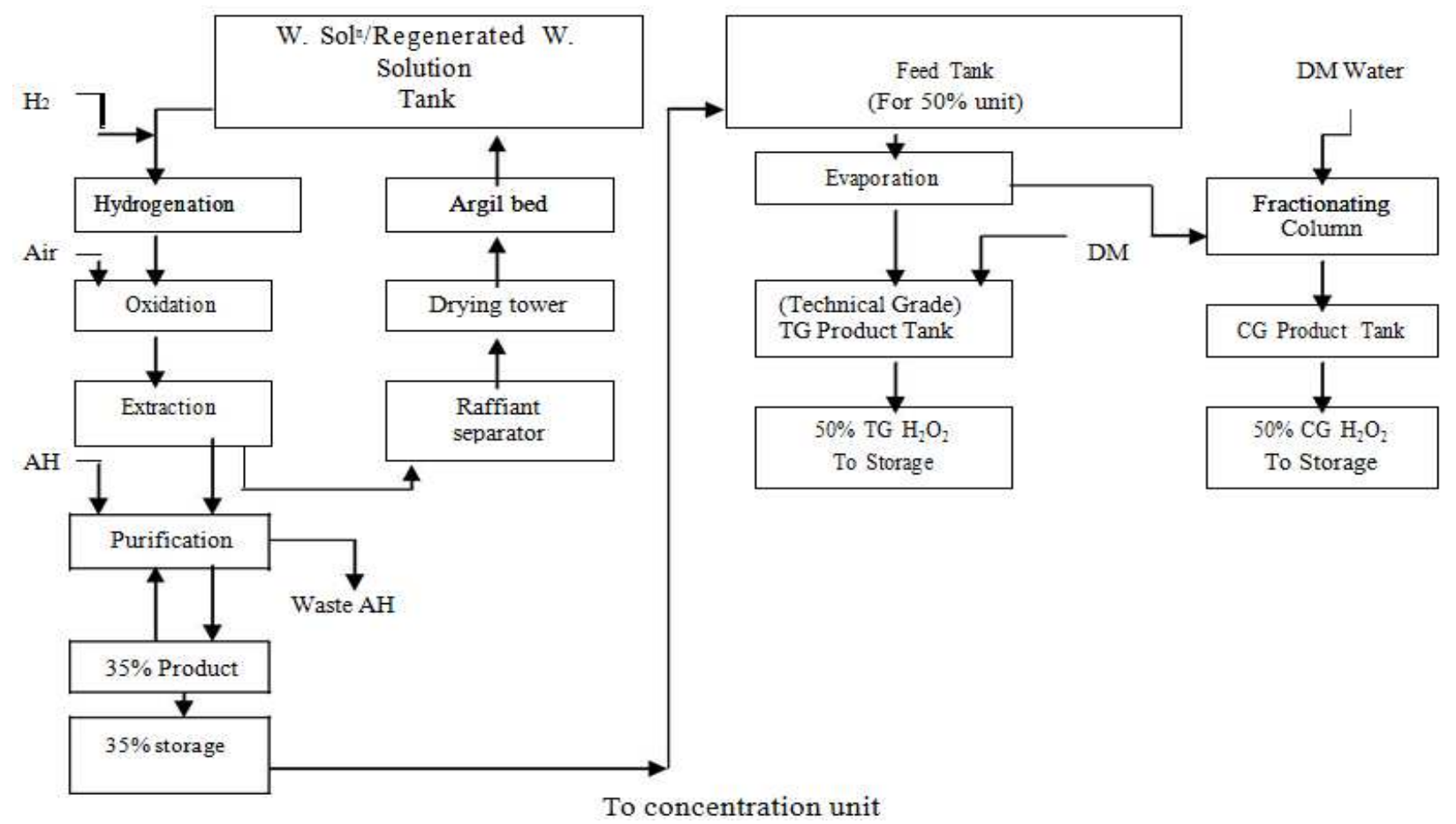

Fig. 4. Block flow diagram for $\mathrm{H}_{2} \mathrm{O}_{2}$ producing plant (organic process plant) 
The facility of utilities must be ensured before setting the hydrogen peroxide plant. The design basis for the utilities and raw material are as follows (https://asmchemical.com; http://www.cncec.com.cn).

Stabilizers can the different chemicals such as phenol, tin, colloidal stannate, organophosphonates, nitrate and acetanilide. Some of the stabilizer is toxic which will not use in the food grade hydrogen peroxide (http://pureh2o2forhealth.com/whatish2o2.htm; http://h2o2uses.com/hydrogen-peroxide-grades-andstabilizers).

\section{Required Equipments}

According to the production capacity of Hydrogen Peroxide, The followings mechanical and electrical equipments, instruments, towers and tanks to be required. To increase the existing plant capacity from 35 TPD to 60 TPD, the new items will be added to this list which is given in the Table 7 (http://www.cncec.com.cn).

\section{Results and Discussion}

Predominantly, hydrogen peroxide produced from the working solution in the presence of aluminum, palladium, oxygen and hydrogen gas through hydrogenation and oxidation. This is called auto oxidation process.
If the amount and purity of raw materials and their dosing rate and ratio are not present in the processing section sufficiently, the production will be slow down and hampered equally, product's quality will not get correctly. Therefore, the amount of raw materials plays an important role in the direct synthesis of hydrogen peroxide. Here has been shown that the raw materials consuming data, equipment's data and operation's data of new an expansion plant. It is generated by our study which is in Table 5 to 7 . Beside this, another report of the study has been shown that user's needs more hydrogen peroxide in Bangladesh for their industrial usage. However, Bangladeshi manufacturers could not meet the local user's demand. So, we saw the great gaps between production capacity and the user's needs which have been shown in Table 1 and 2 . To fill this gap, a current production capacity of hydrogen peroxide should be increased as well as the growth of the industry in the development of Bangladesh. Current plant capacity expansion is essential for long term economic growth and economic resilience of Bangladesh.

Investment cost is needed to consider when to take the planning for installing or expanding the factory. raw materials, equipments, land area, manpower and other utilities are considered in the expanding project.

Table 5. Required utilities for expansion manufacturing plant

\begin{tabular}{|c|c|c|c|}
\hline Name of utilities & Utilities for 35 TPD & Utilities for proposed $60 \mathrm{TPD}$ & Specification \\
\hline Electricity & $1000 \mathrm{KW}$ & $1500 \mathrm{KW}$ & 400 volt, 3 phase, $50 \mathrm{~Hz}$ \\
\hline $\mathrm{NG}$ & $497.5 \mathrm{Nm}^{3} / \mathrm{hr}$ & $582.0 \mathrm{Nm}^{3} / \mathrm{hr}$ & $\mathrm{CH}_{4}-96.0 \%(\mathrm{~min})$ \\
\hline Fuel gas & $84 \mathrm{Nm}^{3} / \mathrm{hr}$ & $120 \mathrm{Nm}^{3} / \mathrm{hr}$ & $\mathrm{CH} 4-96.0 \%(\mathrm{~min})$ \\
\hline DM water & $4.16 \mathrm{~m}^{3} / \mathrm{hr}$ & $6.5 \mathrm{~m}^{3} / \mathrm{hr}$ & $1.00 \mu \mathrm{S} / \mathrm{cm}$ \\
\hline Process water & $25 \mathrm{~m}^{3} / \mathrm{hr}$ & $25-30 \mathrm{~m}^{3} / \mathrm{hr}$ & Underground water \\
\hline Circulating cooling water & $1200 \mathrm{~m}^{3} / \mathrm{hr}$ & $1500 \mathrm{~m}^{3} / \mathrm{hr}$ & $38^{\circ} \mathrm{C}$ to down $30^{\circ} \mathrm{C}$ \\
\hline Steam & $1.00 \mathrm{Ton} / \mathrm{hr}$ & $1.2 \mathrm{Ton} / \mathrm{hr}$ & 8 Bar(g) \\
\hline Process and Instrument Air & $8400 \mathrm{~m}^{3} / \mathrm{hr}, 4.00 \mathrm{Bar}$ & Not require, 4.00 Bar & Clean, oil free \\
\hline itrogen & Pressure $: 0.25 \mathrm{Mpa}$ & Pressure:0.25 Mpa & $99.9 \%$ \\
\hline
\end{tabular}

Table 6. The raw material consumption based on per ton with the specification

\begin{tabular}{|c|c|c|}
\hline Name of raw materials & Consumption/Ton $\mathrm{H}_{2} \mathrm{O}_{2}$ & Specification \\
\hline $\mathrm{H}_{2}$ (Hydrogen) & $256.37 \mathrm{Nm}^{3} /$ Ton & Purity: $98.50 \%, \mathrm{CH}_{4}: 1.0 \%$ \\
\hline Palladium Catalyst & $0.30 \mathrm{Kg} / \mathrm{Ton}$ & Pd content: $0.30 \%$, Bulk Density, $0.5 \mathrm{~g} \mathrm{~mL}^{-1}$ \\
\hline 2-Ethyle Anthra Quinone (2-EAQ) & $1.36 \mathrm{Kg} / \mathrm{Ton}$ & Purity: $98.00 \%$, Melting Point: $107-109^{\circ} \mathrm{C}$ \\
\hline Heavy Aromatics (HA) & $8.00 \mathrm{Kg} /$ Ton & Purity: $98.50 \%$, Sp.gra: 0.875 , Melting point: $107^{\circ} \mathrm{C}$ \\
\hline Tri Octyle Phosphate (TOP) & $1.20 \mathrm{Kg} / \mathrm{Ton}$ & Purity: $99.00 \%$ Flash point: $185^{\circ} \mathrm{C}$, Sp.gra: $0.918-0.924$ \\
\hline Activated Alumina & $10.0 \mathrm{Kg} / \mathrm{Ton}$ & Ø 3-5 mm White Solid \\
\hline Ortho-Phosphoric Acid & $1.60 \mathrm{Kg} / \mathrm{Ton}$ & Purity: $85.00 \%$, Sp.Gr $=1.69$ \\
\hline Ammonium Nitrate & $0.10 \mathrm{Kg} / \mathrm{Ton}$ & Purity: $98.00 \%$, W.Soluble \\
\hline Potassium Carbonate & $3.00 \mathrm{Kg} /$ Ton & Purity: $98.50 \%$ \\
\hline Stabilizer (Acetanilide) & $0.05 \mathrm{Kg} / \mathrm{Ton}$ & Pure \\
\hline Hydrogen Peroxide & 110 Ton as Onetime use & Purity: $35.00 \%$, \\
\hline Nitric Acid & 130 Ton as one time use & Purity: $60.00 \%$, \\
\hline
\end{tabular}


Table 7. Equipment's ID, materials, proposed renovation as usage

\begin{tabular}{|c|c|c|c|c|c|}
\hline $\mathrm{S} / \mathrm{N}$ & ID No. & Name of equipments & Materials & Quantity & Newly require equipments for proposed 60 TPD plant \\
\hline 1 & T102 & Condensate metering tank & SS CS & 1 & Newly Required \\
\hline 2 & T103 & Hy-solution storage vessel & SS CS & 1 & To be Renovated \\
\hline 3 & T104 & Hy-solution argid bed & SS CS & 1 & As Usual \\
\hline 4 & T201 & Phosphoric acid tank & SS & 1 & Newly Required \\
\hline 5 & T202 & $\mathrm{O}_{2}$ ed sol cyclone separator & SS CS & 1 & Newly Required \\
\hline 6 & T203 & $\mathrm{H}_{2}$ soln vent gas separator & SS CS & 1 & Newly Required \\
\hline 7 & T301AB & De-ionized water tank & SS CS & 2 & As Usual \\
\hline 8 & T302 & Raffinate separator & SS CS & 1 & As Usual \\
\hline 9 & T303 & Aromatics header tank & SS CS & 1 & As Usual \\
\hline 10 & T304 & $\mathrm{H}_{2} \mathrm{O}_{2}$ separator & SS CS & 1 & As Usual \\
\hline 11 & T305AB & $\mathrm{H}_{2} \mathrm{O}_{2}$ metering tank & SS CS & 2 & Newly Require \\
\hline 12 & $\mathrm{~T} 401$ & $\mathrm{~W}-$ sol $^{\mathrm{n}}$ metering tank & SS CS & 1 & Newly Require \\
\hline 13 & T402 & $\mathrm{K}_{2} \mathrm{CO}_{3} \mathrm{sol}^{\mathrm{u}}$. settler & SSCS & 1 & As Usual \\
\hline 14 & T403 & $\mathrm{K}_{2} \mathrm{CO}_{3} \mathrm{Sol}^{\mathrm{u}}$. separator & SS CS & 1 & As Usual \\
\hline 15 & T404 & Regenerated $\mathrm{w}-\mathrm{sol}^{\mathrm{n}}$ tank & SS CS & 1 & To be Renovated \\
\hline 16 & $\mathrm{~T} 405$ & Conc. $\mathrm{K}_{2} \mathrm{CO}_{3} \mathrm{sol}^{\mathrm{n}}$ tank & SS CS & 1 & As Usual \\
\hline 17 & T406 & Dilute $\mathrm{K}_{2} \mathrm{CO}_{3} \mathrm{sol}^{\mathrm{n}} \operatorname{tank}$ & SS CS & 1 & As Usual \\
\hline 18 & T407 & Argil bed & SS CS & 1 & Newly Required \\
\hline 19 & T408AB & $\mathrm{W}-\mathrm{sol}^{\mathrm{n}}$ concentration & SS CS & 2 & As Usual \\
\hline 20 & T409 & Working solution tank & SS CS & 1 & To be Renovated \\
\hline 21 & D501 & Solution preparation tank & SS CS & 1 & Newly Required \\
\hline 22 & T501 & Aromatic metering tank & SS & 1 & As Usual \\
\hline 23 & T502 & DM water metering tank & SS & 1 & To be Renovated \\
\hline 24 & T503 & Aromatic metering tank & SS & 1 & Renovation \\
\hline 25 & T504 & Vacuum buffer tank & SS CS & 1 & Newly Required \\
\hline 26 & T505 & Aromatic collecting tank & SS CS & 1 & To be Renovated \\
\hline 27 & T601ABC & Product storage tank & SS CS & 3 & Required as a new \\
\hline 28 & $\mathrm{~T} 602 \mathrm{AB}$ & $\mathrm{H}_{2} \mathrm{O}_{2}$ make-up tank & SS CS & 2 & To be Renovated \\
\hline 29 & T603 & De-ionized water tank & SS CS & 1 & Elevation \\
\hline \multirow[t]{2}{*}{30} & T604 & Metering tank & SS & 15 & As Usual \\
\hline & & & & 15 & As Usual \\
\hline 31 & T605 & Collection tank & SS CS & 1 & As Usual \\
\hline 32 & T901 & Hydrogen storage tank & $\mathrm{CS}$ & 1 & As Usual \\
\hline 33 & T902 & Hydrogen storage tank & CS & 1 & As Usual \\
\hline 34 & T801 & Process air tank & & 1 & As Usual \\
\hline 35 & T802 & Instrument air tank & & 1 & As Usual \\
\hline 36 & $\mathrm{C} 101$ & Hydrogenation tower & SS CS & 1 & To be Renovated \\
\hline 37 & $\mathrm{C} 201$ & Oxidation tower & SS CS & 1 & Renovation \\
\hline 38 & C301 & Extraction tower & SS CS & 1 & Top filler and Screen are renovated \\
\hline 39 & $\mathrm{C} 302$ & Purification tower & SS CS & 1 & To be Renovated \\
\hline \multirow[t]{2}{*}{40} & $\mathrm{C} 401$ & Drying tower & SS CS & 1 & Lower and Upper \\
\hline & & & & & Filler to be renovated \\
\hline 41 & F101 & Nitrogen filter & SS CS & 1 & As Usual \\
\hline 42 & F102 & Hydrogen filter & SS CS & 1 & As Usual \\
\hline 43 & F103 & Outer filter & SS CS & 1 & \\
\hline 44 & F104 & Cyclic filter & SS CS & 1 & As Usual \\
\hline 45 & F201 & Air filter & SS CS & 1 & Newly Required \\
\hline 46 & F501 & W. Sol ${ }^{\mathrm{n}}$ filter & SS CS & & Newly Required \\
\hline 47 & $\mathrm{P} 101 \mathrm{AB}$ & $\mathrm{Hy}^{-S_{0} l^{\mathrm{n}} \text { pump }}$ & & 2 & Newly Required \\
\hline 48 & P201 & Package chiller & & 1 & As Usual \\
\hline 49 & P301AB & De- water pump & & 2 & Newly Required \\
\hline 50 & P302AB & $35 \% \mathrm{H}_{2} \mathrm{O}_{2}$ pump & & 2 & As Usual \\
\hline 51 & $\mathrm{P} 401 \mathrm{AB}$ & Regenerate $\mathrm{w}$-sol ${ }^{\mathrm{n}}$ pump & & 2 & Newly Required \\
\hline 52 & P402 & $\mathrm{K}_{2} \mathrm{CO}_{3}$ soln pump & & 1 & As Usual \\
\hline 53 & P403 & $\mathrm{W}-$ sol $^{\mathrm{n}}$ pump & & 1 & Newly Required \\
\hline 54 & $\mathrm{P} 601 \mathrm{AB}$ & Packing pump & & 2 & As Usual \\
\hline 55 & P602 & Call back pump & & 1 & As Usual \\
\hline 56 & & Hydrogen sol ${ }^{\mathrm{n}}$ ciller & & & As Usual \\
\hline 57 & & Centrifugal compressor & & 4 & Newly Required \\
\hline 58 & & Working sol ${ }^{\mathrm{n}}$ preheater & & & As Usual \\
\hline 59 & & $\mathrm{H}_{2}$ ed tail gas condenser & & & As Usual \\
\hline 60 & & $\mathrm{H}_{2}$ edsol $^{\mathrm{n}}$ filter & & & Newly Required \\
\hline 61 & & Oxidation middle Tower & & & As Usual \\
\hline 62 & & $\mathrm{O}_{2}$ nd tail gas condenser & & & As Usual \\
\hline
\end{tabular}




\section{Use of Hydrogen Peroxide $\left(\mathrm{H}_{2} \mathrm{O}_{2}\right)$}

Hydrogen peroxide is commonly used as bleaching, sanitizing, cleaning agent in the textile industries, pulp and paper industries, leather industries, pharmaceuticals, water and effluent treatment plants. It can also kill micro- organisms. Hydrogen peroxide (in very low concentrations, typically around 5\%) to bleach human hair, hence the phrases "peroxide blonde" and "bottle blonde". It burns the skin upon contact in sufficient concentration. In lower concentrations (3\%), it is used medically for cleaning wounds and removing dead tissue. Combined with urea as carbamide peroxide, it is used for whitening teeth (http://www.americanenergyindependence.com/peroxide aspx). Hydrogen peroxide usage specifically in the following areas:

- Methanol Fuel

- The Alcohol Engine

- Gasification Technology

- National Security

- Energy Crops

- Sustainable Clean Energy Futur

- America's Solar Energy Potentia

- Algae Farms

- Nuclear Energy

- Nuclear Waste Storage

\section{Laboratory for Quality Control}

The purpose of the laboratory is to provide information in the process performance and to carry out quality control testing of hydrogen peroxide. Proprietary equipment is to be used to measure the synthesis loop operation at each stage of the process. To check the products quality and performance of the process operation, A few sophisticated laboratory equipments will require in the laboratory such as gas chromatography, polarography and spectrophotometer etc. Utility testing can be carried out in support of on-line process instrumentation. The laboratory test information is used by operations personnel to control the loop.

\section{Packaging and Transportation}

Hydrogen peroxide is shipped in polyethylene drums of $30 \mathrm{~kg}, 240 \mathrm{~kg}$ and $1 \mathrm{MT}$, IBCs. These drums are fitted with specially designed vented caps to ensure safe storage and transportation.

For bulk quantity customers within Bangladesh, deliver hydrogen peroxide through their dedicated tank-trucks of 12 MT capacities. Services are offered to provide bulk storage of 1,8 and $12 \mathrm{MT}$ in polyethylene construction. For deliveries outside Bangladesh, supply in 30/240 kg polyethylene drums loaded on shipping containers or in isotainers of 20 MT capacities for bulk users (http://www.adityabirlachemicals.com/products/peroxide s/hydrogen_peroxide.html).

\section{Required Manpower}

Minimum quantity of manpower to require for the plant operation is given in the Table 8 (Hydrogen peroxide plant, concentration unites, de-mineralized water plant, gas reforming plant). Generally, operation team, all type of engineering team, technical team, quality team and other expertise works are required during the commissioning period.

\section{Financial Analysis}

The financial analysis of the new hydrogen peroxide project is based on the data presented in the previous chapters and the following assumptions (https://www.academia.edu/13116964/Items_Raw_ma terial_and_Inputs_Utilities_Maintenance_and_repair_ Labour_direct_Factory_over):

- Construction period $=1$ year

- Source of finance $=30 \%$ equity $70 \%$ loan

- $\quad$ Tax holidays $=5$ years

- Bank interest $=10-12 \%$

- Discount cash flow $=8.5 \%$

- Accounts receivable $=30$ days

- Raw material local $=30$ days

- Work in progress $=2$ days

- Finished products $=30$ days

- $\quad$ Cash in hand $=5$ days

- Accounts payable $=30$ day

\section{Total Initiative Investment Cost}

The total investment cost of the hydrogen peroxide project including working capital is estimated at USD5, $00,00,00.00$. The major breakdown of the total initial investment cost is shown in Table 7.

Initial Investment Cost (https://www.academia.edu/13116964/Items_Raw_mater ial_and_Inputs_Utilities_Maintenance_and_repair_Labo ur_direct_Factory_over):

- Land lease value or own

- Building and Civil Work

- Plant Machinery and Equipment

- Office Furniture and Equipment

- Lab Instruments

- Vehicle

- Pre-production Expenditure

- Working Capital 
Table 8. Require manpower with cost in Bangladesh especially when plant is ongoing (https://www.academia.edu/13116964/Items_Raw_material_and_Inputs_Utilities_Maintenance_and_repair_Labour_direct_ Factory_over)

\begin{tabular}{llll}
\hline Designated manpower & Qty. & Monthly salary (USD) & Annual cost (USD) \\
\hline General Manager & 1 & 1500.00 & 4000.00 \\
Technical Manager (Mech. + Chem. + Elce. + QC.) & 4 & 1000.00 & 4800.00 \\
Administration Manager & 1 & 2500.00 & 12000.00 \\
Officer/Chemist/Engineer (Tech + Product) & 5 & 3500.00 & 30000.00 \\
Operator/Fitter/Lab Analyst/Electrician & 12 & & 42000.00 \\
Total & & 150000.00 \\
\hline
\end{tabular}

Pre-production expenditure includes interest during construction, commissioning training, costs of registration, licensing and formation of the company including legal fees, commissioning expenses, etc.

\section{Conclusion}

In this article the limitation is that the detailed areas of the plant did not explain which was important in the operation and expansion of the existing hydrogen peroxide plant. Activation of alumina, regeneration working solution, normal shutdown procedures, hydrogen generation unit, concentration unite, cooling water system, de-mineralized water system and waste management are not discussed in the study. In our study, we sort out the lack of knowledge regarding the market demand, plant expansion, production procedure, chemical's calculation, operation method and costing with investment. It can be helpful or beneficial to manufacturer, users, business planners and operation people in this area. On the other hand, in view of the huge prospect in the textile, agriculture, tannery, pharmaceuticals and wastewater treatment is the demand for $\mathrm{H}_{2} \mathrm{O}_{2}$ going to increase in the near future. With the overall industrialization trends in Bangladesh, new hydrogen peroxide plants are required to install in Bangladesh or, the existing plants are required to increase the production capacity. Besides this, we have to present us with a unique opportunity for service and gain huge profit while adding to the country's GDP (Gross Domestic Product).

\section{Acknowledgment}

This review article was fully supported by $\mathrm{Mr}$. Zoynal Abedin Chowdhury, CEO, ASM Chemical Industries Ltd. We thank my colleagues Mr. Sultan Salauddin and Mr. Mehedi Hasan, ASM Chemical Industries Limited who's provided insight and expertise that greatly assisted the review although they may not agree in all area of this review.

We would also like to show our gratitude to another colleagues named Mr. Salim Mia, Mr. Susen Debnath,
Mr. Anisur Rahman and Mr. Hekmot Ali for sharing their field expertise with us. We are also immensely grateful to well wishers for their comments and suggestions on this review article, although any error are our own and should not tarnish the reputations of these esteemed persons.

All authors contribution in preparation, development and publication this review article

\section{Funding Information}

The review works has been completed by Author's own funded.

\section{Author's Contribution}

All authors contribution in area of preparation, development and publication this review.

\section{Ethics}

This article is original and contains unpublished material. The corresponding author confirms that all of the other authors have read and approved the manuscript and no ethical issues involved.

\section{References}

http://chemcollective.org/activities/tutorials/stoich/calcul ating_molecular_weight

$\mathrm{http}: / / \mathrm{h} 2 \mathrm{o} 2$ uses.com/hydrogen-peroxide-grades-andstabilizers

http://nzic.org.nz/ChemProcesses/production/1E.pdf

http://pureh2o2for health.com/whatish2o2.htm

http://www.adityabirlachemicals.com/products/peroxides /hydrogen_peroxide.html

http://www.americanenergyindependence.com/peroxide. aspx

http://www.cncec.com.cn (Plant Manual of China National Chemical Equipment Corporation)

http://www.h2o2.com/technical-library/physicalchemical-properties

http://www.idconline.com/technical_references/pdfs/che mical_engineering/Preparing_to_Manufacture_Hydr ogen_Peroxide.pdf

https://asmchemical.com(Plant Manual) 
https://en.wikipedia.org/wiki/

https://www.academia.edu/13116964/Items_Raw_materi al_and_Inputs_Utilities_Maintenance_and_repair_L abour_direct_Factory_over

https://www.diyspaceexploration.com/preparingmanufacture-hydrogen-peroxide

Kato, T., Y. Ishiuchi, H. Takamiya, K. Ogasawara and K. Minato, (n.d.). Process for producing hydrogen peroxide.
Kosydar, R., A. Drelinkiewicz and J.P. Ganhy, 2010. Degradation reactions in anthraquinone process of hydrogen peroxide synthesis. Catalysis Lett., 139: 105-113. DOI: 10.1007/s10562-010-0413-1

Salahuddin, M.S., 2011. Prospect and challenges of basic chemicals industries Bangladesh. J. Chem. Eng., 26: 27-79. 